\title{
Comparison of REP13E12 PCR with Amplicor MTB for the Detection of Mycobacterium tuberculosis in Respiratory Specimens
}

\author{
Tae-Yoon Lee \\ Department of Microbiology, \\ College of Medicine, Yeungnam University, Daegu, Korea
}

-Abstract-

Backgrounds : In recent years, the incidence of tuberculosis has increased mainly in high-risk populations. Classical laboratory diagnostic methods for tuberculosis have low sensitivity and time consuming procedures. Thus, it is important to identify the presence of Mycobacterium tuberculosis in the clinical specimens earlier than the culture results for the decision to initiate anti-tuberculosis therapy. Lee et al. reported a species-specific repeated sequence from a Korean M. tuberculosis isolate, which was later proved to be a part of REP13E12 repetitive sequence.

Materials and Methods : In this study, we compared the acid-fast staining, culture, Amplicor MTB (Roche), and REP13E12 PCR for detection of M. tuberculosis using 88 clinical samples. The sensitivity, specificity, positive and negative predictive values were compared.

Results : REP13E12 PCR showed equivalent score to Amplicor MTB. Both PCR-based methods showed better score than conventional stain and culture methods.

Conclusion: This result suggested that REP13E12 PCR is helpful for the rapid detection of the $M$. tuberculosis from clinical specimens.

Key Words: Mycobacterium tuberculosis, Detection, REP13E12-PCR

Introduction

Tuberculosis is a major health problem that affects 8 million people and is responsible

책임저자 : 이태윤, 대구광역시 남구 대명5동 317-1, 영남대학교 의과대학 미생물학교실

Tel: (053) 620-4362, Fax: (053) 653-6628, E-mail: doxr7p@med.yu.ac.kr 
for about 2 million deaths each year., ${ }^{1,2)}$ It is important to detect $M$. tuberculosis in clinical specimens quickly so that anti-tuberculosis drug therapy can be initiated. Several investigators have reported the PCR detection of $M$. tuberculosis DNA in clinical specimens ${ }^{3-10)}$ Most of them were based on the IS6110 repetitive sequence. ${ }^{11)}$ IS6110 is present in $M$. tuberculosis isolates with a copy number of 0-25. Thus, there are M. tuberculosis isolates without this repeated sequence. Lee et al. (GenBank U43540, 1995) reported a repeat sequence of $453 \mathrm{bp}$, from a Korean M. tuberculosis isolate, which is specific to the strains belonging to $M$. tuberculosis complex. $^{12)}$ In 1998, this repeat was proved to be a part of REP13E12 repetitive sequence from the genomic sequence data of $M$. tuberculosis H37Rv. ${ }^{13)}$ In this study, we examined the usefulness of REP13E12-based polymerase chain reaction (PCR) by comparing with Amplicor MTB kit (Roche Molecular System, Branchburg, N.Y.), acid fast stain, and culture method for the detection of $M$. tuberculosis from clinical specimens.

\section{Materials and Methods}

\section{Specimens and processing methods}

Eighty-eight Korean clinical isolates from patients who were suspected to have pulmonary tuberculosis were obtained from Daegu-Gyungbuk Branch of the Korean Association of Tuberculosis. To minimize the possibility of PCR contamination, DNA extraction, PCR amplification, and detection processes were carried out in separate rooms with different pipettes and tips with barriers. Equal volume of $4 \% \mathrm{NaOH}$ was added to the specimen, vortex-mixed and incubated at room temperature for $15 \mathrm{~min}$ to decontaminate general bacteria. Two and a half volume of $0.067 \mathrm{M}$ phosphate buffer ( $\mathrm{pH}$ 6.8) was added and the mixture was centrifuged at 3,000 r.p.m. for $20 \mathrm{~min}$. The decontaminated specimen was neutralized with $1 \mathrm{~N} \mathrm{HCl}$ solution by dropping. These procedures were carried out within 24 hours after the specimen was received. Specimens were subjected to acid-fast stain, culture, REP13E12 PCR, and Amplicor MTB tests.

\section{Staining}

Conventional Ziehl-Neelsen acid-fast staining method was used. AFB was reported on the basis of the following criteria at a 1000-fold magnification: no AFB seen, negative; one to nine per slide, few; one to nine per field, moderate; greater than nine per field, many.

\section{Culture}

Each $100 \mu l$ of decontaminated specimens were inoculated onto each of two Ogawa slants. The inoculated media were cultured 4-8 weeks at $37^{\circ} \mathrm{C}$.

\section{REP13E12 PCR}

DNA in the sputum specimens was prepared 
as follows: decontaminated sputum pellets $(200 \mu \ell)$ were mixed with $100 \mu l$ of zirconium beads ( $0.1 \mathrm{~mm}$ in diameter), $100 \mu$ of distilled water, and $300 \mu l$ of phenol-chloroformisoamylalcohol (25: 24: 1, v: v). The mixture was shaken in a Mini-bead beater for $5 \mathrm{~min}$ and centrifuged at $10,000 \mathrm{x} \mathrm{g}$ for $10 \mathrm{~min}$. The DNA in the aqueous phase was precipitated by addition of 2.5 volume of absolute ethanol. The DNA was dissolved in $30 \mu l$ of TE (pH8.0) and used for PCR. ${ }^{14)}$ Following primers were used for REP13E12 PCR; Forward: 5'-ACGTCAAAGTGATTCG CG-3' and Reverse: 5'-CATGCCGTCGTAT TGCTG -3 '. The PCR mixture contained 10 $\mathrm{mM}$ Tris- $\mathrm{HCl}$ (pH 8.3), $50 \mathrm{mM} \mathrm{KCl}, 1.5$ $\mathrm{mM} \mathrm{MgCl}_{2}, 0.1 \%$ Triton $\mathrm{X}-100,0.5 \mathrm{mM}$ of each primers, $200 \mathrm{mM}$ of each of the 4 deoxyribonucleoside triphosphates (Boehringer Mannheim), $2.5 \mathrm{U}$ of AmpliTaq (Perkin-Elmer Cooperation, Norwalk, Conn.), and appropriate amounts of DNA prepared from bacterial strains or clinical specimens. ${ }^{15)}$ The PCR cycle was $5 \mathrm{~min}$ denaturation at $95^{\circ} \mathrm{C}$, then 30 cycles (each cycle was $95^{\circ} \mathrm{C}$ for $1 \mathrm{~min}, 65^{\circ} \mathrm{C}$ for $1 \mathrm{~min}$, and $72^{\circ} \mathrm{C}$ for $2 \mathrm{~min}$ ), and a final extension cycle of $7 \mathrm{~min}$ at $72^{\circ} \mathrm{C}$ in a PerkinElmer 480 Cycler (Perkin-Elmer Cooperation, Norwalk, Conn.).

\section{Amplicor MTB}

The Amplicor MTB test was performed with instructions supplied by the manufacturer. A $100 \mu l$ of each sample was mixed with the wash solution and the mixture was centrifuged at $12,500 \times \mathrm{g}$ for $10 \mathrm{~min}$. The supernatant was discarded and the pellet was resuspended with lysis reagent and incubated in a $60^{\circ} \mathrm{C}$ water bath for $45 \mathrm{~min}$. The lysate was neutralized with $100 \mu l$ of neutralization reagent provided with the kit. The processed specimen $(50 \mu \ell)$ was mixed with a 50 ul of master mixture solution containing biotin-labeled primers, nucleotides, and DNA polymerase. This system amplifies the $584 \mathrm{bp}$, 16S rRNA fragment of mycobacteria. The amplicon was chemically denatured and hybridized with probes specific for the $\mathrm{M}$. tuberculosis complex. The biotin-labeled amplicons were identified by colorimetric detection (A450). A colorimetric reading exhibiting absorbance values greater than 0.35 optical density units was considered as positive.

\section{Results}

All 88 sputum specimens were examined by AFB stain, culture, REP13E12 PCR, and Amplicor MTB. Of the 88 specimens, 12 were smear positive, 15 were culture positive, 16 were Amplicor MTB positive, and 17 were REP13E12 PCR positive. The specimens divided into 9 groups as summarized in Table 1. Group I, positive in all of the tests; Group II, smear-negative and other tests positive; Group III, culture-negative and other tests positive; Group IV, smear- and 
- Comparison of REP13E12 PCR with Amplicor MTB for the Detection of Mycobacterium tuberculosis in Respiratory Specimens -

Table 1. Interpretation and grouping according to each test results

\begin{tabular}{ccccccc}
\hline Group & Interpretation & $\begin{array}{c}\text { No. of } \\
\text { samples }\end{array}$ & AFB stain & Culture & $\begin{array}{c}\text { Amplicor-MT } \\
\text { REP13E12 }\end{array}$ & \begin{tabular}{c} 
PCR \\
\hline I
\end{tabular} \\
II & $\mathrm{Tb}$ & 9 & + & + & + & + \\
III & $\mathrm{Tb}$ & 2 & - & + & + & + \\
$\mathrm{IV}$ & $\mathrm{Tb}$ & 1 & + & - & + & + \\
$\mathrm{V}$ & $\mathrm{Tb}$ & 3 & - & - & + & + \\
$\mathrm{VI}$ & $\mathrm{Tb} *$ & 1 & + & - & + & - \\
$\mathrm{VII}$ & $\mathrm{Tb*}$ & 2 & - & + & - & + \\
$\mathrm{VII}$ & $\mathrm{MOTT}$ & 1 & + & - & - & - \\
$\mathrm{IX}$ & MOTT & 2 & - & + & - & - \\
\hline
\end{tabular}

$\mathrm{Tb}:$ M. tuberculosis, MOTT : mycobacteria other than tubercle bacilli, Group I to VI : M. tuberculosis positive, Group VII to IX : M. tuberculosis negative, * : false positive,

culture- negative and REP13E12- and Amplicor MTB-positive; Group V, smear- and Amplicor MTB- positive and culture- and REP13E12negative; Group VI, smear- and Amplicor MTB-negative and culture- ${ }^{-}$and REP13E12 PCR-positive; Group VII, smear-positive and all other tests negative; Group VIII, culturepositive and all other tests negative; Group IX, negative in all of the tests. All tests were duplicated.

Eighteen specimens that were positive at least two methods out of four (Group I to VI) was regarded these as golden positive standards. Thus, 70 samples were golden negative standards. Group VII and VIII, positive with only one method, were regarded as false positives (probably mycobacteria other than tubercle bacilli, MOTT). The

Table 2. Comparison of tests for detection of $M$. tuberculosis in clinical specimens

\begin{tabular}{|c|c|c|c|c|c|c|c|}
\hline \multirow{2}{*}{ Method } & \multirow[t]{2}{*}{ Result } & \multicolumn{2}{|c|}{$\begin{array}{c}\text { Sample No. of } \\
\text { final interpretation }\end{array}$} & \multirow{2}{*}{$\begin{array}{c}\text { Sensitivity } \\
(\%)\end{array}$} & \multirow{2}{*}{$\begin{array}{c}\text { Specificity } \\
(\%)\end{array}$} & \multicolumn{2}{|c|}{ Predictive value(\%) } \\
\hline & & Positive & Negative & & & Positive & Negative \\
\hline \multirow{2}{*}{ Stain } & Positive & 11 & 1 & \multirow{2}{*}{61.1} & \multirow{2}{*}{98.6} & \multirow{2}{*}{91.7} & \multirow{2}{*}{90.8} \\
\hline & Negative & 7 & 69 & & & & \\
\hline \multirow{2}{*}{ Culture } & Positive & 13 & 2 & \multirow{2}{*}{72.2} & \multirow{2}{*}{97.1} & \multirow{2}{*}{86.7} & \multirow{2}{*}{93.2} \\
\hline & Negative & 5 & 68 & & & & \\
\hline \multirow{2}{*}{$\begin{array}{c}\text { Amplicor } \\
\text { MTB }\end{array}$} & Positive & 16 & 0 & \multirow{2}{*}{88.9} & \multirow{2}{*}{100} & \multirow{2}{*}{100} & \multirow{2}{*}{97.2} \\
\hline & Negative & 2 & 70 & & & & \\
\hline \multirow{2}{*}{ REP13E12 PCR } & Positive & 17 & 0 & \multirow{2}{*}{94.4} & \multirow{2}{*}{100} & \multirow{2}{*}{100} & \multirow{2}{*}{98.6} \\
\hline & Negative & 1 & 70 & & & & \\
\hline
\end{tabular}


specimens that have the same test results with 4 test methods were 76 (77.3\%).

The sensitivities, specificities, positive predictive values, and negative predictive values of each test were summarized in Table 2. The results showed that the sensitivities/specificities of AFB stain, culture, REP13E12, and Amplicor MTB were 61.1/98.6(\%), 72.2/97.1(\%), 94.4/100(\%), and 88.9/100(\%), respectively.

The positive predictive values of smear, culture, REP13E12, and Amplicor MTB were 91.7\%, 86.7\%, 100\%, 100\%, while the negative predictive values were 90.8\%, 93.2\%, 97.2\%, 98.6\%, respectively. Amplicor MTB and REP13E12 were more sensitive (88.9\% and 94.4\%) and specific (each 100\%) methods than smear or culture methods for the detection of the $M$. tuberculosis. There were no statistically significant differences between sensitivities of Amplicor MTB and REP13E12.

\section{Discussion}

Both REP13E12 PCR and Amplicor MTB use PCR amplification of $M$. tuberculosisspecific DNA. However, REP13E12 PCR uses M. tuberculosis-specific primers while Amplicor MTB uses primers amplifying the DNA region encoding $16 \mathrm{~S}$ rRNA that is common to all mycobacterial species, which was used for hybridization with $M$. tuberculosisspecific probes. This two-step procedure might explain the lower sensitivity found in
Amplicor MTB method, even though the results were not statistically significant.

AFB staining is very simple and rapid but has been known to be not sensitive. Usually AFB stain-positive is reported when more than ten thousands bacilli are present in specimens. The culture method showed $72.2 \%$ sensitivity and 97.1\% specificity. The relatively low sensitivity of culture might be due to the complex procedures for decontamination which could kill $M$. tuberculosis bacilli in the specimens. The high sensitivity of amplification-based methods might be due to they uses DNA, which is very stable, not live bacilli for the tests.

The increased incidence of tuberculosis in not only underdeveloped countries but developed countries, due to the spread of human immunodeficiency virus (HIV) infection, has stimulated the need of rapid and direct detection methods for the laboratory identification of $M$. tuberculosis. Although numbers of investigators have reported PCR-based detection of $M$. tuberculosis, REP13E12 PCR is the only method that uses DNA sequence of a Korean $M$. tuberculosis isolate. The results of this study also suggested that PCR-based methods are simple, rapid, and acceptable for the detection of $M$. tuberculosis in clinical specimens.

\section{요 약}

배경 : 최근 결핵의 발병이 고위험군을 중심으 
로 증가하고 있다. 기존의 결핵 진단법은 오랜 시간이 걸리면서도 낮은 민감도를 가지고 있 다. 따라서, 배양 결과 전에 빠른 치료 시작을 위해 임상 가검물에서 결핵균의 존재를 확인하 는 것이 매우 중요하다. 이 등은 한국 결핵균 분리주로부터 종특이 반복서열을 발견하였고 이는 후에 REP13E12 반복서열임이 밝혀졌다.

재료 및 방법 : 본 연구에서 저자는 88개의 임 상가검물에서 결핵균을 검출하기 위해 항산성 염색, 배양, Amplicor MTB (Roche) 및 REP $13 \mathrm{E} 12 \mathrm{PCR}$ 법들을 비교하였다. 특히, 민감도, 특이도, 양성 및 음성 예측율을 비교하였다.

결과 : REP13E12 PCR법은 Amplicor MTB법 과 동등한 결과를 보였다. 이 두 가지 방법은 기존의 염색 및 배양법에 비해 보다 나은 성적 을 보였다.

결론:이 결과는 REP13E12 PCR법이 임상가 검물에서 결핵균을 신속히 검출하는데 유용함 을 시사하였다.

\section{References}

1. Bloom BRC, Murray CJL. Tuberculosis: commentary on a reemergent killer. Science 1992; 257: 1055-64.

2. Kochi A. The global tuberculosis situation and the new control strategy of the World Health Organization. Tubercle 1991; 72: 1-6.

3. Eisenach KD, Cave MD, Bates JH, Crawford JT. Polymerase chain reaction amplification of a repetitive DNA sequence specific for Mycobacterium tuberculosis. J Infect Dis 1990; 161: 977-81.

4. Hermans PWM, van Soolingen D, Dale JW, Schuitema ARJ, McAdam RA, Catty D, et al.. Insertion element IS986 from Mycobacterium tuberculosis: a useful tool for diagnosis and epidemiology of tuberculosis. J Clin Microbiol 1990; 28: 2051-58.

5. Thierry D, Brisson-Noel A, Vincent-LevyFrebault V, Nguyen S, Guesdon JL, Gicquel B. Characterization of a Mycobacterium tuberculosis insertion sequence, IS6110, and its application in diagnosis. Journal of Clinical Microbiology 1990; 28: 2668-73.

6. Eisenach KD, Sifford MD, Cave MD, Bates JH, Crawford JT. Detection of Mycobacterium tuberculosis in sputum samples using a polymerase chain reaction. Am Rev Resp Dis 1991; 144: 1160-63.

7. van Soolingen D, De Haas PEW, Hermans PWM, Groenen PMA, van Embden JDA. Comparison of various repetitive DNA elements as genetic markers for strain differentiation and epidemiology of Mycobacterium tuberculosis. J Clin Microbiol 1993; 31: 1987-95.

8. Anderson AB, Thybo S, Godfrey-Faussett P, Stocker NG. Polymerase chain reaction for detection of Mycobacterium tuberculosis in sputum. Eur J Clin Microbiol Infect Dis 1993; 12: 922-27.

9. Wilson SM, McNerney R, Nye PM, GodfreyFaussett PD, Stocker NG, Voller A. Progress toward a simplified polymerase chain reaction and its application to diagnosis of tuberculosis. J Clin Microbiol 1993; 31: 776-82.

10. Schluger NW, Kinney D, Harkin TJ, Rom WN. Clinical utility of the polymerase chain reaction in the diagnosis of infections due to Mycobacterium tuberculosis. Chest 1994; 105: 1116-21.

11. McAdam RA, Hermans PWM, van Soolingen D, Zainuddin ZF, Catty D, van Embden JDA, et al. Characterization of a Mycobacterium tuberculosis insertion sequence belonging to the IS3 family. Mol Microbiol 1990; 4: 1607-13. 
12. Lee TY, Lee TJ, Belisle JT, Brennan PJ, Kim SK. A novel repeat sequence specific to Mycobacterium tuberculosis complex and its implications. Tubercle Lung Dis 1997; 78: 13-19.

13. Cole ST, Brosch R, Parkhill J, Garnier T, Churcher C, Harris D, et al. Deciphering the biology of Mycobacterium tuberculosis from the complete genome sequence. Nature 1998; 393: 537-44.
14. Sambrook J, Fritsch EF, Maniatis T. Molecular cloning: a laboratory manual, 2nd ed. Cold Spring Harbor Laboratory Press, Cold Spring Harbor, NY, 1989, pp. 9.31-9.62.

15. Saiki RK, Gelfand DH, Stoffel S, Scharf SJ, Higuchi R, Horn GT, et al. Primer-directed enzymatic amplification of DNA with a thermostable DNA polymerase. Science 1988; 239: 487-91. 